\title{
Postcolonial translation: theory and practice
}

Book or Report Section

Accepted Version

Goff, B. (2014) Postcolonial translation: theory and practice. In: Encyclopedia of Ancient Greek Language and Linguistics. Brill, Leiden, pp. 122-125. ISBN 9789004225978 Available at http://centaur.reading.ac.uk/37983/

It is advisable to refer to the publisher's version if you intend to cite from the work. See Guidance on citing.

Published version at: http://www.brill.com/encyclopedia-ancient-greek-language-and-linguistics

Publisher: Brill

All outputs in CentAUR are protected by Intellectual Property Rights law, including copyright law. Copyright and IPR is retained by the creators or other copyright holders. Terms and conditions for use of this material are defined in the End User Agreement. 


\section{CentAUR}

Central Archive at the University of Reading

Reading's research outputs online 
Postcolonial Translation: Theory and Practice

Postcolonial translation, or adaptation, refers to the rewriting of classical works within or for modern postcolonial societies. By 'postcolonial' we usually understand the period after former colonies achieve independence, often at the midpoint of the $20^{\text {th }} \mathrm{c}$., but it may also refer to works of opposition or resistance produced under colonialism. Given that post-independence periods in some countries have been marked by continuing forms of oppression not directly tied to European imperialism, 'postcolonial' can also include resistance to neo-colonialism.

Although postcolonial writers have sometimes translated Greek and Latin texts in order simply to disseminate them more widely, their creative efforts have been more often directed towards 'adaptation', to producing new works of literature that acknowledge classical works as part of their genesis but then rewrite them. This activity of adaptation is part of 'classical reception', a term which encompasses the various ways in which classical texts and artifacts have been reused by subsequent cultures. Postcolonial adaptation offers particular insight into this larger cultural process.

Gilbert and Tompkins 1996 recognized that classical literature informed a notable proportion of postcolonial drama, and discussed this development under the rubric of 'canonical counter-discourse'. This term suggested that the postcolonial writing 'countered' the 'canon', which was understood to consist of the highlights of western literature both by Greeks and Romans and by more modern Europeans. This model of canonical counter-discourse drew on earlier work such as Ashcroft et al 1989, which, while very influential, has also been criticized. Briefly, the criticism queries the 
hierarchy which endows the imperial metropolis with the canon, perhaps at some unquestioned 'centre', and confines the colonies to writing 'back to' it from the position of marginalised aftercomers. Recent criticism has elaborated further models which are more varied and open.

Adaptation may be termed a 'deliberate, announced, and extended revisitation of prior works' (Mee and Foley 2011: 8, quoting Hutcheon 2006) such that an oscillation is set up between the prior and the current, with neither predominating; the relationship between the two works is lateral rather than vertical. Yet the colonial situation, which gives rise to the postcolonial adaptations, was undoubtedly structured by vertical hierarchy. Colonialism is widely recognised to have worked via an inculcation of cultural superiority as well as by military and technological might, and such assumed superiority was often explained by the European colonizers' fantasized descent from Greece and Rome. In this context, the strategies of the colonized could include adopting versions of Greece and Rome for their own, as well as asserting the claims of indigenous cultural resources. For several postcolonies a further tactic can be to show that the colonized culture possesses its own separate relationship to the classical societies, unmediated by colonial occupation; India and Egypt, for instance, can show links to ancient Greece which bypass modern Europe. Adaptations of classical literature in those contexts can underline those relationships.

That the postcolonial adaptations are not translations was not always clear to commentators; Soyinka's The Bacchae of Euripides, for instance, was criticized for not being an accurate rendering of Euripides (Goff 2006), and plays and poems might routinely be discussed in terms of their 'fidelity' to originals, or 'authenticity' as versions of originals, rather than being analysed as creative works in their own right. The 
immense upsurge in classical reception activity over the last fifty years or so, and the development of postcolonial literary theory, have worked to ensure a more sophisticated critical response. Classical adaptations form part of the creative traditions of all countries which experienced European colonization, and they contribute to those countries' negotiations with all aspects of the postcolonial condition. Issues such as national or local identity, gender relations, political or cultural violence, corruption and democratic deficit, historical memory, and linguistic struggles, have all been treated via the prism of engagement with classical models. Conversely, classical cultures can lay claim to an important role in the formation of modern postcolonial societies.

One of the most striking of postcolonial adaptations is Derek Walcott's 1990 poem Omeros, an epic poem that implicitly draws on the Iliad and Odyssey, as well as Oedipus, Dante and Joyce, to represent the contemporary Caribbean. The postcolonial themes of the wounds of history, slavery and loss, and the possibilities of art and redemption, are sifted through characters who recall classical prototypes while refusing to be simply identified with them. Although the characters may be called Philoctete, Achille, Hector and Helen, the narrative voice tries also to reject their classical associations:

Why not see Helen

As the sun saw her, with no Homeric shadow,

Swinging her plastic sandals on that beach alone 
When would the sails drop

From my eyes, when would I not hear the Trojan War

In two fishermen cursing in Ma Kilman's shop?

271

Instead of these constraining classical identifications, critics show that the poem invokes a number of cultures which help to produce the contemporary Caribbean, and that the multiplicity of characters offers different versions of history and lineage. Greek figures are in circulation, not only integral to European cultures, and are thus available to be indigenized (Goff and Simpson 2007: 259); the multiple traditions of the Caribbean mean that nothing simply 'refers', whether to ancient Greece or some other historical condition (Greenwood 2010: 38). Walcott himself has inveighed against the notion that Omeros is 'a reinvention of the Odyssey, but this time in the Caribbean. I mean, what would be the point of doing that? What this implies is that geologically, geographically, the Caribbean is secondary to the Aegean. What this does immediately is to humiliate the landscape...' (Walcott 1997:232). In his essay 'The Muse of History' he has similarly resisted the tyranny of 'history as time' in favor of a more enabling 'history as myth' (1974:1). Emily Greenwood has more recently examined the diversity of Anglophone Caribbean literature to suggest that it is informed by the classical tradition, not as a hierarchy of one-way influence, but as a sustained dialogue in which authors 'read the Caribbean through Greece and Rome and, conversely...read Greece and Rome through the Caribbean' (2010:7).

Although interest has centered on poetry, epic and otherwise, in the case of Walcott and other Caribbean writers who have drawn on classical tropes, much of the 
literature characterized by classical adaptation is dramatic. In the former British colonies of Nigeria and Ghana, flourishing indigenous theatrical traditions were appropriating classical models as early as the 1960s, even as they worked to develop cultural forms that would be appropriate to independent nations. In the case of South Africa, Athol Fugard's famous version of Antigone, The Island, is credited with helping to galvanize western opposition to apartheid when it came to London (Kruger 1999:13). The Greek plays of African descent have attracted substantial critical attention (Wetmore 2002, Budelmann 2005, Hardwick 2004, 2005, Goff and Simpson 2007) and an increasingly impressive history of productions and performances. Within the critical assessments, certain themes recur which can also be relevant to postcolonial adaptation in other contexts.

Many critics note that African adaptations draw heavily on indigenous ritual forms, suggesting that ritual is one important area in which ancient Greek culture overlaps with that of many African societies. In Ola Rotimi's The Gods Are Not to Blame, a rewriting of Oedipus Tyrannus, the Yoruba system of Ifa divination replaces the Delphic oracle, and in Efua Sutherland's Edufa, which invokes Alcestis, the Admetusfigure has consulted a diviner and obtained a charm which will allow him to live if another dies for him, rather than being gifted with that possibility by deity. In several of the adaptations, however, 'traditional' African ritual also comes into conflict with modern assumptions about logic and rationality, pointing to the plays' double genesis in African forms and forms acquired through colonization.

Along with an emphasis on ritual goes a highly developed use of the chorus, which links the African plays more securely to the Greek genre than is the case for many Western adaptations. While the latter sometimes reduce the Greek chorus to a single 
figure, as in Anouilh's Antigone, African adaptations deploy collectives seriously and skillfully. In Osofisan's Tegonni, the lone rebel of Greek tradition is joined by a trio of equally feisty friends, and in Soyinka's The Bacchae of Euripides the chorus of maenadic women is matched by a new chorus of slaves. Such innovations can also alter the gender dynamics of the plays, and several of the dramas draw on the Greek tradition of challenging, heroic females to address gender inequalities in their own societies; this is especially noticeable in the case of Osofisan (Olaniyan 1999), but it can also be read as early as Sutherland. Conversely, The Island explores women's subjection by means of the transvestite acting of the male protagonist (Rehm 2007).

The 'double genesis', the plays' plural origins in forms both indigenous and colonial, is explicitly acknowledged in several features, not least the language. Although written mostly in English, African adaptations may include passages of various length in Yoruba or other languages, which may or may not be translated for the Anglophone reader. If we suppose a western reader, unfamiliar with the African language, that reader confronts the difficulty of moving between cultures which is one of the products of colonialism. The double genesis is often addressed via the topic of the plays, because African adaptations are inclined to deal with the tragedies of extreme resistance and revenge such as Medea and Antigone, inviting us to read them as contestations of imperial dominance. Insofar as western dominance also produced the very forms that the plays take, however, the plays are always potentially identified with what they ostensibly reject, in an oedipal dynamic examined by Goff and Simpson 2007. Other critics emphasize that the plays are in the process of emancipating themselves from such dominance (Budelmann 2005, Hardwick 2005). 
Creative activity in Anglophone African and Caribbean countries has made certain postcolonial adaptations particularly well known. In very recent years, however, more detail is emerging about classical adaptations in other postcolonial societies, which will reshape understanding of the classical tradition in general. Thus Phiroze Vasunia (2007) has analysed an Indian version of Aristophanes' Wealth and the ways in which it addressed contemporary social concerns, including those arising from British colonialism, and Peter Pormann (2012) has undertaken a similar study of several Arabic engagements with Aristophanes. Both scholars situate these analyses of adaptations in the context of other work with the classical tradition undertaken by writers in the cultures concerned (Vasunia and Hall 2010, Pormann 2009). In South America, Andrew Laird (2006) has uncovered a history of writing in Latin among indigenous people, which can underline the work of Moira Fradinger (2011) on adaptations of Antigone in the Americas. In a fitting culmination to the story of postcolonial adaptation, Fradinger suggests not that Antigone in the Americas is the scar left by colonialism, but that it is in fact an indigenous 'national tradition' (2011:68).

Barbara Goff (University of Reading)

\section{Bibliography}

Ashcroft, Bill, Gareth Griffiths and Helen Tiffin, ed. 1989. The empire writes back: theory and practice in post-colonial literatures. London 
Budelmann, Felix. 2005. 'Greek tragedies in West African adaptations'. In: Goff ed., 118-146.

Fradinger, Moira. 2011. 'An Argentine tradition'. In: Mee and Foley 67-89

Gilbert, Helen and Joanne Tompkins. 1996. Post-colonial drama. London

Goff, Barbara and Michael Simpson. 2007. Crossroads in the black Aegean: Oedipus, Antigone and dramas of the African diaspora. Oxford

Goff, Barbara ed. 2005. Classics and colonialism. London

Goff, Barbara. 2006. 'Dionysiac triangles: the politics of culture in Wole Soyinka's The Bacchae of Euripides', The soul of tragedy, ed. by Victoria Pedrick and Steven Oberhelman, 73-90. Chicago

Greenwood, Emily. 2010. Afro-Greeks: dialogues between Anglophone Caribbean literature and classics in the twentieth century. Oxford

Hardwick, Lorna. 2004. 'Greek drama and anti-colonialism: de-colonising classics', Dionysus since '69: tragedy at the dawn of the millennium, ed. E. Hall, F. Macintosh and A. Wrigley, 219-244. Oxford

Hardwick, Lorna. 2005. 'Refiguring classical texts: aspects of the post-colonial condition'. In: Goff ed, 107-117.

Hutcheon, Linda. 2006. A theory of adaptation. New York and London Kruger, Loren. 1999. The drama of South Africa: plays, pageants, and publics since 1910. London

Laird, Andrew. 2006. The epic of America. London 
Mee, Erin and Helene Foley ed. 2011. Antigone on the contemporary world stage. Oxford

Olaniyan, Tejumola. 1999. 'Femi Osofisan: provisional notes on the post-colonial incredible', (Post) Colonial stages: critical and creative views on drama, theatre and performance, ed. by Helen Gilbert, 174-89. Hebden Bridge Pormann, Peter. 2009. 'Classics and Islam: from Homer to al-Qa'ida', International Journal of the Classical Tradition 16.2:197-233

Pormann, Peter. 2012. 'Arabs and Aristophanes, Menander among the Muslims: Greek humour in the medieval and modern Middle East', Ancient Comedy and Reception: Studies in the Classical Tradition of Comedy from Aristophanes to the Twenty-First Century, Dedicated to Jeffrey J. Henderson, ed. by Wolfgang Haase, 1-38. New Brunswick, NJ

Rehm, Rush. 2007. ' "If you are a woman”: theatrical womanizing in Sophocles' Antigone and Fugard, Kani, and Ntshona's The Island, Classics in postcolonial worlds, ed. by Lorna Hardwick and Carol Gillespie, 211-227. Oxford Vasunia, Phiroze and Edith Hall ed. 2010. India, Greece, and Rome, 1757-2007. London Vasunia, Phiroze. 2007. 'Dalpatram's Lakshmi and Aristophanes' Wealth', Aristophanes in Performance 412 BCE-2005 CE, ed. by Edith Hall and Amanda Wrigley, 117-134. Oxford Walcott, Derek. 1974. "The muse of history", Is massa day dead?, ed. Orde Coombs, 127. New York 
Walcott, Derek. 1997. 'Reflections on Omeros', The poetics of Derek Walcott: intertextual perspectives, ed. by Gregson Davis, 229- 246. Special issue of the South Atlantic Quarterly, 96.2

Wetmore, Kevin J. Jr. 2002. The Athenian sun in an African sky. Jefferson NC Keywords:

Postcolonial; adaptation; colonialism; imperialism; Walcott; Soyinka; Osofisan; Omeros; ritual; chorus; gender; language; Africa; Caribbean; Arabic; Indian; canonical counterdiscourse; Antigone 